\title{
ANALYSIS AND MODELLING OF PETROPHYSICAL PARAMETERS OF THE MAIN DOLOMITE FORMATION ON THE BASIS OF WELL LOGGING AND SEISMIC DATA
}

\author{
Magdalena NIEPSUJ \& Paulina KRAKOWSKA \\ AGH University of Science and Technology, Faculty of Geology, \\ Geophysics and Environment Protection, Department of Geophysics; \\ al. A. Mickiewicza 30, 30-059 Krakow, Poland; \\ e-mail:niepsuj@geol.agh.edu.pl,krakow@agh.edu.pl
}

\begin{abstract}
The Main Dolomite is one of the most prospective hydrocarbon reservoir formations in Poland. The goal was to determine the Main Dolomite zonation in selected part of carbonate platform sedimentation area and also to analyze the influence of cementation factor on water saturation by well logging and seismic data integration. Well logging interpretation quantitatively characterized petrophysical parameters. Seismic inversion presented the distribution of the parameters at vertical and horizontal scales. Basic statistical calculations of petrophysical parameters, 2D crossplots and seismic inversion were made. The central part of the Main Dolomite interval indicated the best reservoir properties. High porosity values and low P-wave velocity, low bulk density and low water saturation values were observed in the analyzed zone. Mudlogging confirmed the occurrence of gas. Determination of hydrocarbon saturation in carbonates is a challenge for well logging interpretation and geophysical interpretation. The cementation factor is one of the main coefficients in petrophysics which strongly affect water saturation. Adopting the wrong value of this parameter causes serious error in the coefficient of the water saturation value. In the paper, water saturation was modeled using the Borai equation and Shell formula. By using the computed water saturation and fluid substitution method theoretical velocities of $\mathrm{P}$-waves and S-waves (also P-wave/S-wave velocity ratio) were calculated. Results of the comprehensive interpretation of logs are the basis for lithology determination but P-wave and S-wave velocity can also serve as a source information about lithology. In reservoir rocks $V_{P} / V_{S}$ ratio may also work as a confirmation of gas saturation.
\end{abstract}

Key words: the Main Dolomite, lithofacies zone, petrophysical parameters, cementation factor, Borai formula, Shell formula, fluid substitution, seismic inversion

\section{INTRODUCTION}

The Main Dolomite Formation (Zechstein) became one of the most perspective reservoir of the second carbonate level of the cyclic Zechstein evaporate series. Combining results of well logging and seismic interpretation enabled us to estimate reservoir properties. 
As a result of the depth bottom diversity of reservoir several sedimentation zones of the Main Dolomite were formed (Fig. 1): basin floor, platform slope, toe-of-slope, barriers, platform (Jaworski \& Mikołajewski 2007). Vertical variety reservoir parameters were also indicated within each the Main Dolomite lithofacies zone. The analyzed area is a natural reef sedimentation environment in a local paleoelevation of the shelf.

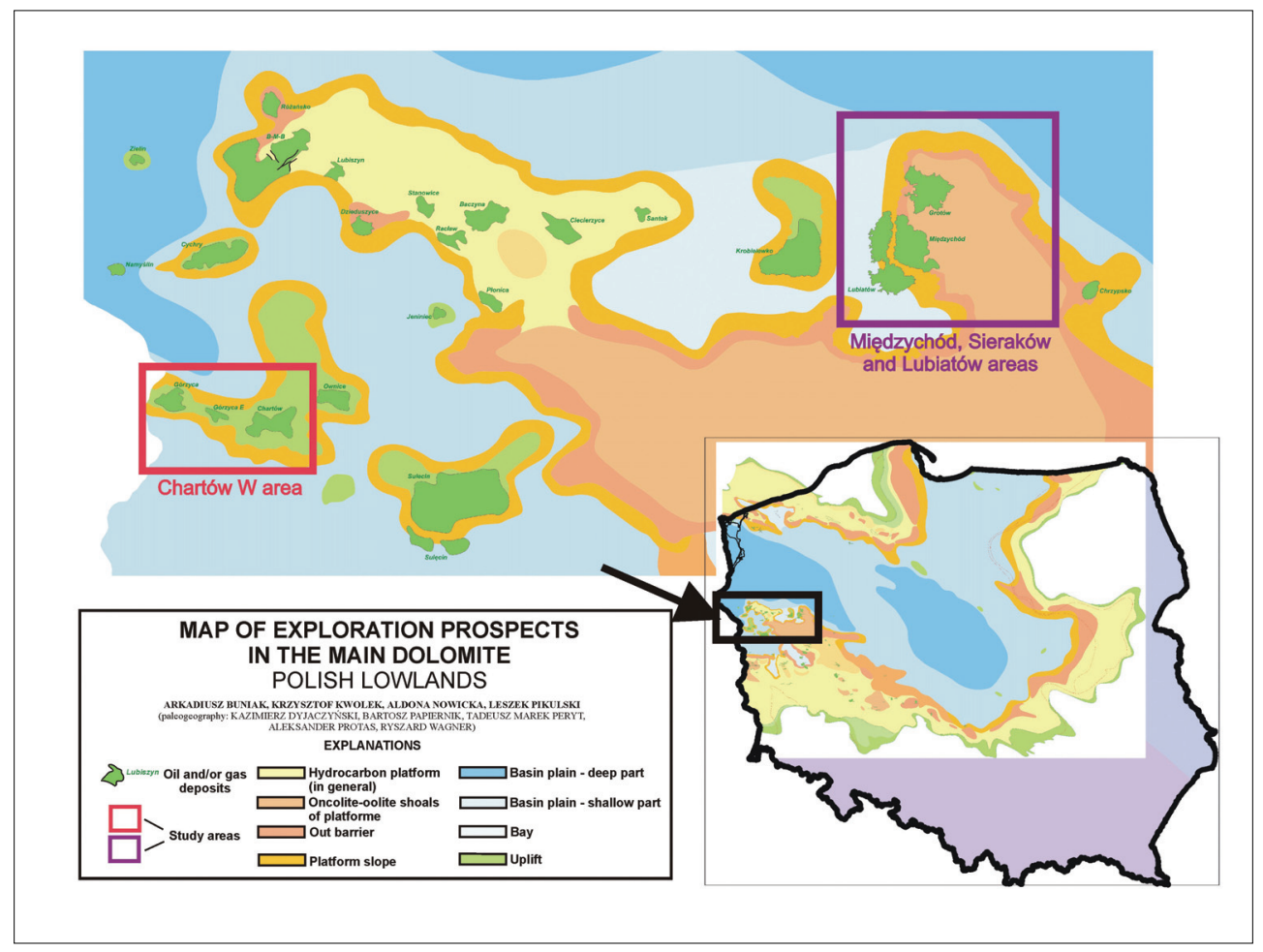

Fig. 1. Paleographic map of the Main Dolomite Ca2 (Wagner et al., 2000, modified) with highlighted location of Chartów W area and A well (red rectangle) and Gorzów platform (Międzychód, Sieraków, Lubiatów areas) (purple rectangle)

The goal was to analyze well logging and seismic parameters of the Main Dolomite formation and attempt to divide the formation into zones with similar properties. Seismic data was used as a tool to analyze and interpret the available data using seismic inversion. Furthermore, an alternative method of cementation factor selection in gas-bearing carbonates was discussed, to improve water saturation estimation. Well logging data from the northwest part of Poland (well A, Fig. 1) were used to show that the value of the cementation factor strongly influenced water saturation and consequently calculated P-wave and S-wave velocity values. 


\section{MATERIAL AND METHODS}

The studied material comprised well logging (set of logs) and seismic data (seismic sections) from Chartów W area. The subject of the analysis was the Main Dolomite formation. All calculations were carried out using GeoWin software (Jarzyna et. al. 2002), Hampson-Russell software (Veritas 2004) and GeoGraphix Discovery software (Landmark_AGH UST University Grant).

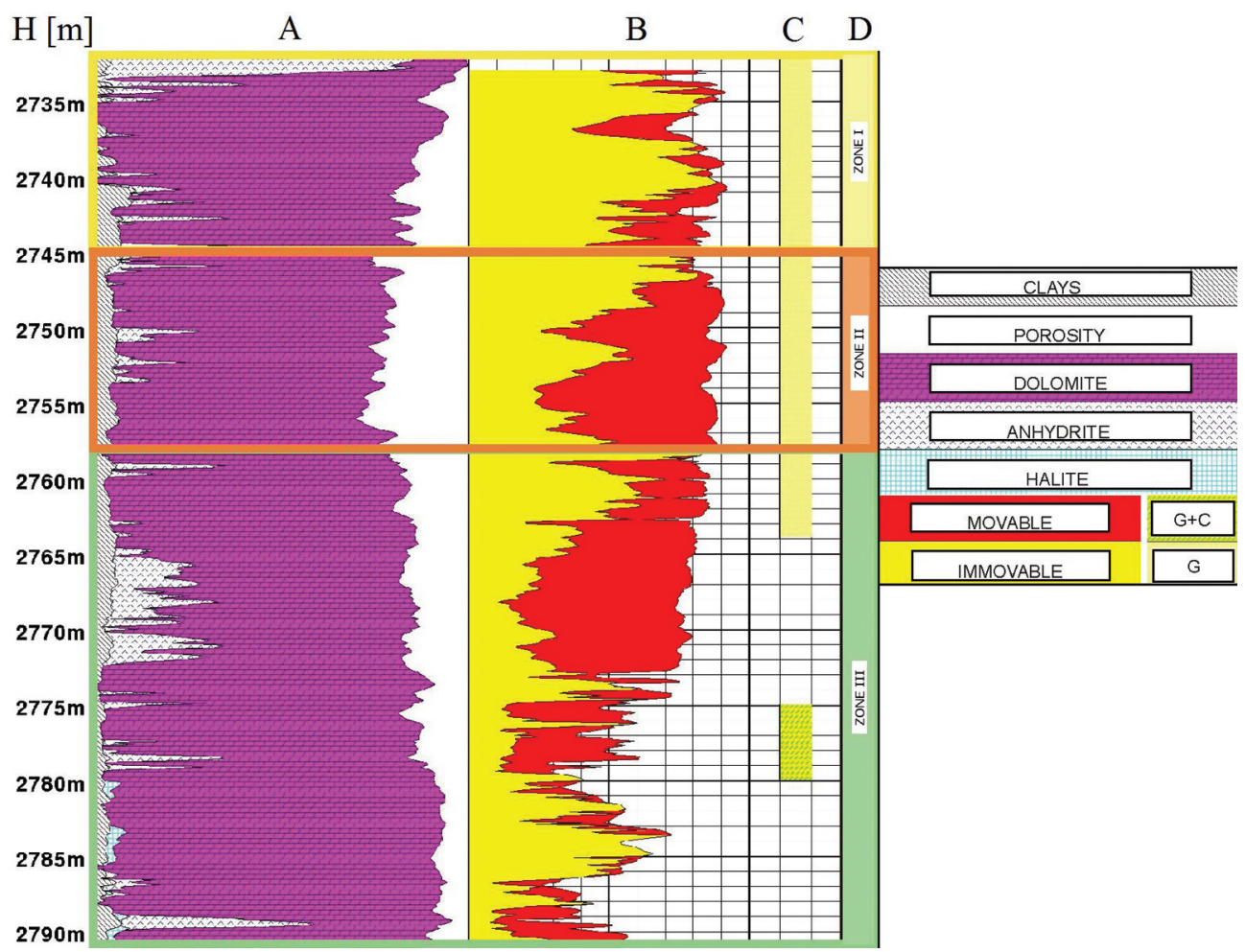

Fig. 2. Litho-porosity solution of the analyzed interval of Main Dolomite in well A (acc. to Geofizyka Torun solution). Sections: A - lithology, B - moveable and immovable hydrocarbons, $\mathrm{C}$ - gas-bearing intervals, D - interpreted zonation division. Symbols: G+C - gas condensate interval, $\mathrm{G}-$ gas interval

Well logging data were delivered from A well which drilled the Main Dolomite in the lagoonal zone (Fig. 2). The analyzed interval was $2733-2791 \mathrm{~m}$. The available data contained the following logs: gamma ray (GR), bulk density (RHOB), P-wave velocity $\left(V_{P}\right)$, resistivity $\left(R_{t}\right)$, total porosity (PHI) and also water saturation $\left(S_{W}\right)$ (Krakowska \& Niepsuj 2010). Basic statistical calculations (minimum, maximum, average, standard deviation values) were carried out on the following parameters: P-wave velocity, bulk density, gamma ray, deep resistivity, 
porosity and water saturation (Tab. 1). Several types of 2D crossplots (i.e. P-wave velocity vs. porosity, P-wave velocity vs. water saturation) were made using petrophysical parameters (Fig. 3) in GeoWin software. On the base of statistical calculations and parameters characterization by $2 \mathrm{D}$ crossplots the three zones of different parameters in the Main Dolomite were determined: zone I from $2733 \mathrm{~m}$ to $2745 \mathrm{~m}$, zone II from $2745 \mathrm{~m}$ to $2758 \mathrm{~m}$ and zone III from $2758 \mathrm{~m}$ to $2791 \mathrm{~m}$. For parameters from each zone basic statistics were calculated (Tab. 2). Results for only P-wave velocity and porosity are presented in Table 2.

Table 1

Basic statistics for Main Dolomite in the analysed interval: 2733-2791 m in well A. Symbols: $\mathrm{N}$ - number of data, MIN - minimum value, MAX - maximum value, AV. - average value, S.D. - standard deviation

\begin{tabular}{|l|c|c|c|c|c|}
\cline { 2 - 6 } \multicolumn{1}{c|}{} & $\mathrm{N}$ & MIN & MAX & AV. & S.D. \\
\hline$V_{P}[\mathrm{~m} / \mathrm{s}]$ & 59 & 3778 & 5878 & 4986 & 552 \\
\hline RHOB [g/cm $\left.{ }^{3}\right]$ & 59 & 2.18 & 2.85 & 2.52 & 0.16 \\
\hline GR [API] & 59 & 27 & 117 & 58 & 17 \\
\hline RT [omm] & 59 & 2.28 & 114.17 & 19.32 & 20.80 \\
\hline PHI [frac] & 59 & 0.03 & 0.30 & 0.15 & 0.06 \\
\hline SW [frac] & 58 & 0.09 & 0.85 & 0.29 & 0.20 \\
\hline
\end{tabular}

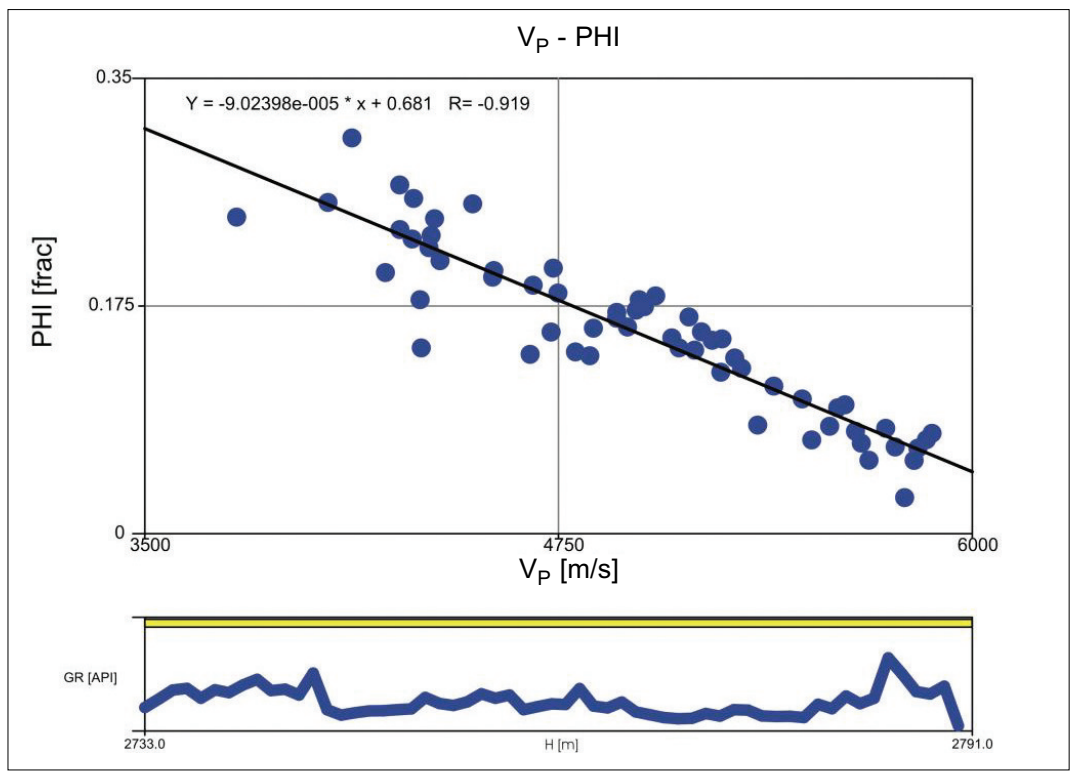

Fig. 3. Crossplot $P$ - wave velocity $V_{P}$ versus porosity PHI 
Table 2

Basic statistics for each zone of Main Dolomite in the analysed interval: $2733-2791 \mathrm{~m}$ in well A. Symbols as in Table 1

\begin{tabular}{|l|l|c|c|c|c|c|}
\cline { 3 - 7 } \multicolumn{2}{c|}{} & $\mathrm{N}$ & MIN & MAX & AV. & S.D. \\
\hline \multirow{2}{*}{ zone 1 } & $V_{P}[\mathrm{~m} / \mathrm{s}]$ & 12 & 4227 & 5795 & 4913 & 543 \\
\cline { 2 - 7 } & PHI [frac] & 12 & 0.03 & 0.20 & 0.13 & 0.06 \\
\hline \multirow{2}{*}{ zone 2 } & $V_{P}[\mathrm{~m} / \mathrm{s}]$ & 14 & 3778 & 4555 & 4301 & 206 \\
\cline { 2 - 7 } & PHI [frac] & 14 & 0.20 & 0.30 & 0.24 & 0.03 \\
\hline \multirow{2}{*}{ zone 3 } & $V_{P}[\mathrm{~m} / \mathrm{s}]$ & 33 & 4734 & 5879 & 5304 & 349 \\
\cline { 2 - 7 } & PHI $[\mathrm{frac}]$ & 33 & 0.06 & 0.20 & 0.13 & 0.04 \\
\hline
\end{tabular}

Zone I is characterized by porosity values from 0.03 to 0.2 , with average value equal to 0.13 and the highest standard deviation (0.06). P-wave velocity values reach the average value equal to $4913 \mathrm{~m} / \mathrm{s}$ and the highest standard deviation $\left(543(\mathrm{~m} / \mathrm{s})^{2}\right)$. Zone II is represented by the highest porosity values $(0.24)$, changing from 0.2 to 0.3 , with the lowest standard deviation (0.03). P-wave velocity values reach the lowest values (minimum, maximum, average, standard deviation). In zone III the situation is different, namely the porosity values range from 0.06 to 0.2 , with average value equal to 0.13 , and standard deviation 0.04 . $\mathrm{P}$-wave velocities reach the highest values.

3D seismics from the study area was also available. Seismic section to well logging tying, phase boundary correlation and seismic inversion processes were made within the frame of standard seismic interpretation (Niepsuj 2009). Model-based seismic inversion was carried out in Hampson-Russell software (Veritas 2004). The basic inversion was presented in pseudo-velocity mode (Fig. 4). The inverse porosity mode was derived after the determination of porosity vs. P-wave velocity relationship (crossplots) (Fig. 5). The results of seismic inversion are presented in Figures 4 and 5.

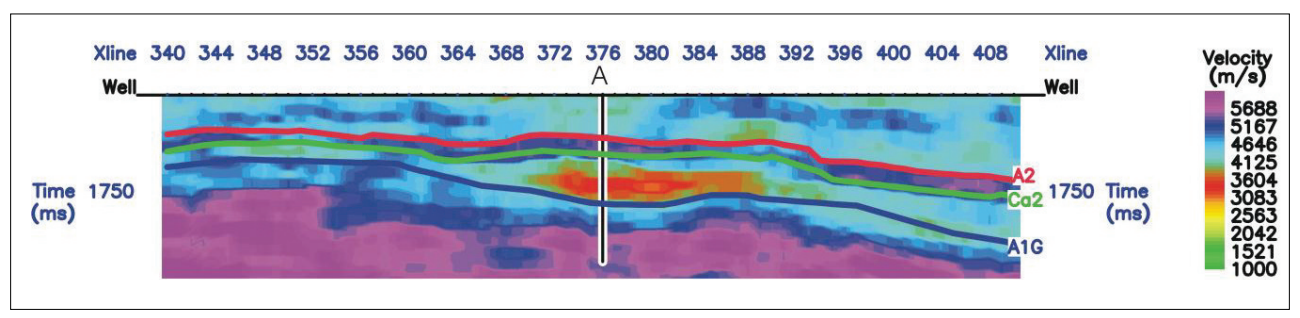

Fig. 4. Result of seismic inversion for a part of seismic section (inline 546)

(Niepsuj 2009) 


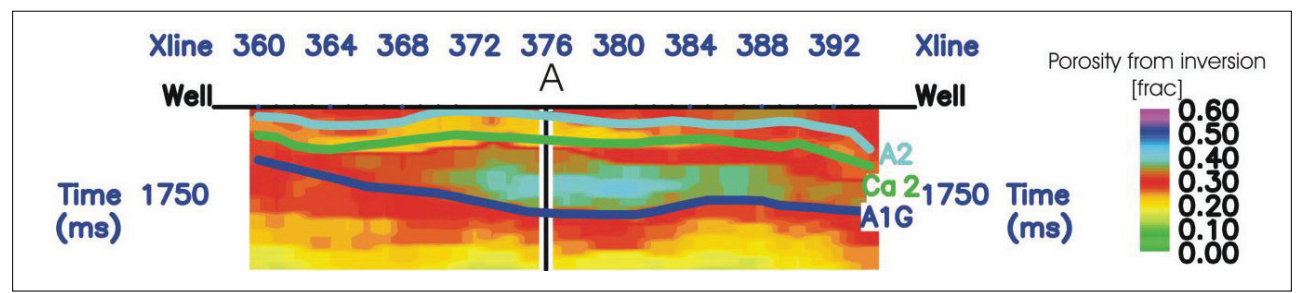

Fig. 5. Result of seismic inversion for a part of seismic section (inline 546) in inversion porosity mode

After estimating the porosity and formation thickness of the Main Dolomite the next step in the reservoir interpretation was undertaken and several approaches to proper water saturation determination were done. In the standard interpretation of water saturation calculation in carbonates the cementation factor is set to 2. It may be one of the reasons of errors in gas volume estimation. Modelling of water saturation assuming different cementation factor values was carried out to improve the gas saturation estimation in gas-bearing zones. Borai (1987) discovered one of the most important formulas for cementation factor calculation. It was determined for the offshore carbonates of Abu Dhabi (Tab. 3). In the Borai case cementation factor decreases with decreasing porosity. An opposite result comes from the Shell formula where an increase in the cementation factor correlates with a decrease in porosity (Tab. 3).

Table 3

Formulas for cementation factor calculation

\begin{tabular}{|c|c|c|}
\hline Borai formula & Shell formula & Symbols \\
\hline$m=2.2-\frac{0.035}{\Phi+0.042}$ & $m=1.87-\frac{0.019}{\Phi}$ & $\begin{array}{l}m-\text { cementation factor } \\
\Phi-\text { effective porosity }\end{array}$ \\
\hline
\end{tabular}

A general form of the Shell formula is used also for carbonates. Both, Borai and Shell formula, were calculated for low-porosity carbonates (Borai 1987). Carbonates of the Main Dolomite in the analyzed interval (2700-2800 m) are a reservoir of low-porosity (Niepsuj 2009). The first step in the cementation factor analysis was based on the calculation of an average cementation factor for the analyzed interval (Krakowska 2009). After using Borai formula (Tab. 3) the result $m=1.88$ was obtained and after using Shell formula (Tab. 3) $m=2$.6. Laboratory analysis on core samples provided $m=2$ (routine core analysis). In the next step water saturation was interpreted (Fig. 6) for the obtained cementation factors. Before the water saturation calculation GeoWin software was applied to make borehole and environmental correction to resistivity. The next method of the reliability estimation of the Borai and Shell formulas was the fluid substitution method. All calculations were carried out in GeoGraphix Discovery software fluid substitution tool. First, S-wave velocity was evaluated from wet $V_{P}-V_{S}$ estimation using P-wave velocity and bulk density values and Brie's equation GeoGraphix Discovery Software fluid substitution tool for $n=5$ and $V_{P}-V_{S}$ constants (Greenberg-Castagna equation, Bała 2009). Having P-wave velocity (well log), 
S-wave velocity (wet $V_{P}-V_{S}$ estimation, Brie's equation for $n=5$ ) and various water saturation (Fig. 6) changes in P-wave and S-wave velocities were examined depending on gas saturation (Hampson-Russell Guide: crossplots). Formation should not be considered as an isotropic one but as an anisotropic model. Brie's equation was used to estimate P-wave and $\mathrm{S}$-waves velocities necessary to carry out the analysis because it minimizes the isotropy assumption in the calculations.

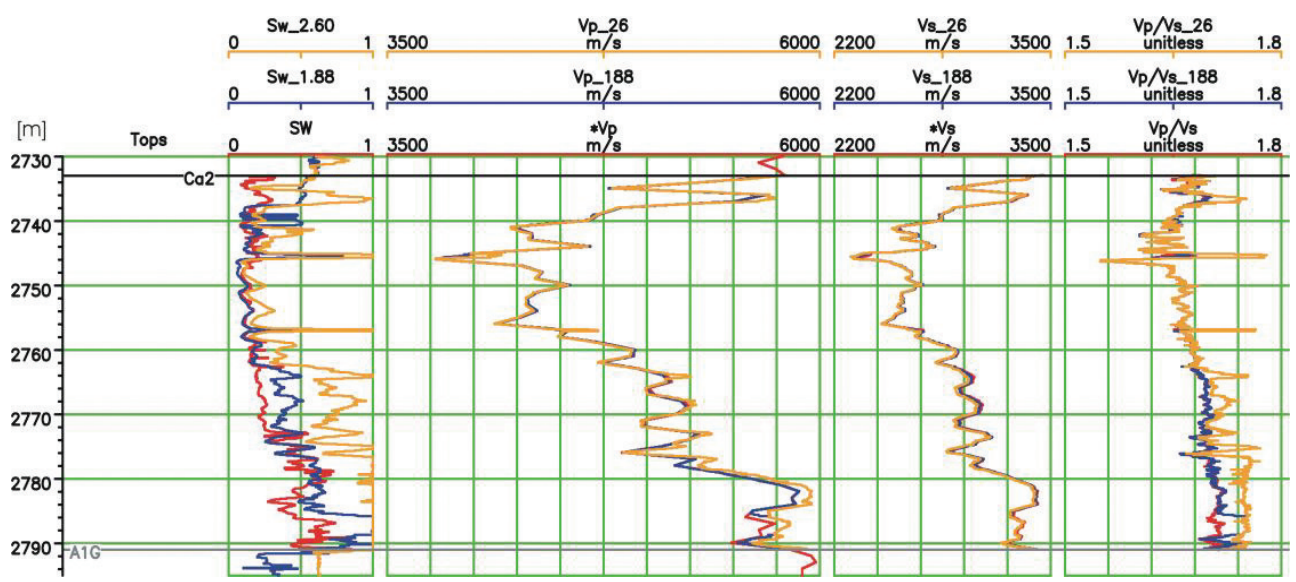

Fig. 6. Water saturation $S_{W}$, P-wave velocity $V_{P}$, and S-wave velocity $V_{S}$ in the study section of well A (Sw_2.6 - water saturation obtained adopting $m=2.6$, Sw_1.88 - water saturation obtained adopting $m=1.88$, SW - water saturation obtained adopting $m=2, \mathrm{Vp} \_26$ - P-wave velocity calculated for water saturation obtained adopting $m=2.6, \mathrm{Vp} \_188$ - P-wave velocity calculated for water saturation obtained adopting $m=2.6, * \mathrm{Vp}-\mathrm{P}$-wave velocity calculated for water saturation obtained adopting $m=2, \mathrm{Vp} \_26-\mathrm{S}$-wave velocity calculated for water saturation obtained adopting $m=2.6$, Vs_188 - S-wave velocity calculated for water saturation obtained adopting $m=1.88$, *Vs $-\mathrm{S}$-wave velocity calculated for water saturation obtained adopting $m=2, \mathrm{Vp} / \mathrm{Vs} \_26-\mathrm{P}$-wave/S-wave ratio calculated for water saturation obtained adopting $m$ $=2.6, \mathrm{Vp} / \mathrm{Vs} \_188-\mathrm{P}$-wave/S-wave ratio calculated for water saturation obtained adopting $m=1.88, \mathrm{Vp} / \mathrm{Vs}-\mathrm{P}$-wave/S-wave ratio calculated for water saturation obtained adopting $m=2$, Ca2 - Main Dolomite top, A1G - Main Dolomite bottom)

\section{RESULTS}

Combining the well logging and seismic interpretation results enabled the estimation of reservoir properties. The Main Dolomite formation may be divided into three zones, as was observed after well logging analysis. Petrophysical parameters statistical analysis and crossplots interpretation determined the zonation division. Seismic inversion results confirmed the zonation. The most perspective zone was recognized in $2745-2758 \mathrm{~m}$ (zone II) in A well and characterized with high porosity values and a decrease in P-wave velocity, bulk density and water saturation values (Tabs 1, 2, Fig. 2). On the part of the seismic section, anomalous velocities zone is visible within the Main Dolomite formation (Figs 4, 5). 
The highest velocity decrease appeared in the central analyzed level of the Main Dolomite. Zone of anomalous values of parameters was marked in Figure 4. The relation between P-wave velocity and porosity enabled us to present inversion results in the inversion porosity mode (Fig. 5). High inversion porosities were observed also in the central part of the Main Dolomite. The zones were categorized on the basis of the best reservoir parameters quality: II, I and III. There are known gas-bearing intervals from the Geofizyka Toruń interpretation: 2733-2763 m and 2775-2780 m (Fig. 2). Zones I and II contain in 2733-2763 gasbearing interval, the second gas-bearing interval contain in zone III and reached only $5 \mathrm{~m}$.

Correct estimation of cementation factor is essential for proper porosity and water saturation determination in well log interpretation. Differences in computed water saturation using different cementation factors: $m=1.88, m=2.00, m=2.60$ are significant, water saturation calculated adopting $m=2.60$ reached the highest values, often equal to 1 , instead of water saturation calculated adopting $m=1.88$. The highest gas saturation occurred for cementation factor $m=1.88$, and the lowest for $m=2.60$. Fluid substitution option is a procedure for P-wave and S-wave velocities calculations putting diverse water saturation (Bała 2008). Changes in P-wave velocities are observed more often than in S-waves. $V_{P} / V_{S}$ ratio showed better discrepancy. Decreasing of the $V_{P} / V_{S}$ ratio may be treated as a gas indicator in reservoir rocks. The gas-bearing intervals from the Geofizyka Torun interpretation: 2733-2763 $\mathrm{m}$ and $2775-2780 \mathrm{~m}$ correlate with the water saturation calculated adopting $m=1.88$. In those intervals the $\mathrm{P}$-wave velocity, the $\mathrm{S}$-wave velocity and also the $V_{P} / V_{S}$ ratio curves are parted for different water saturations: lower values calculated for water saturation obtained adopting $m=1.88$, and higher for $m=2.60$ (Fig. 6). The interval between two gas-bearing layers showed velocity discrepancy because of large differences in water saturation calculated adopting $m=1.88, m=2.00$ and $m=2.60$. Crossplot 3D for $V_{P} / V_{S}$ (axis Y), $S_{W}$ (axis X) and porosity (color key) is presented in Figure 7.

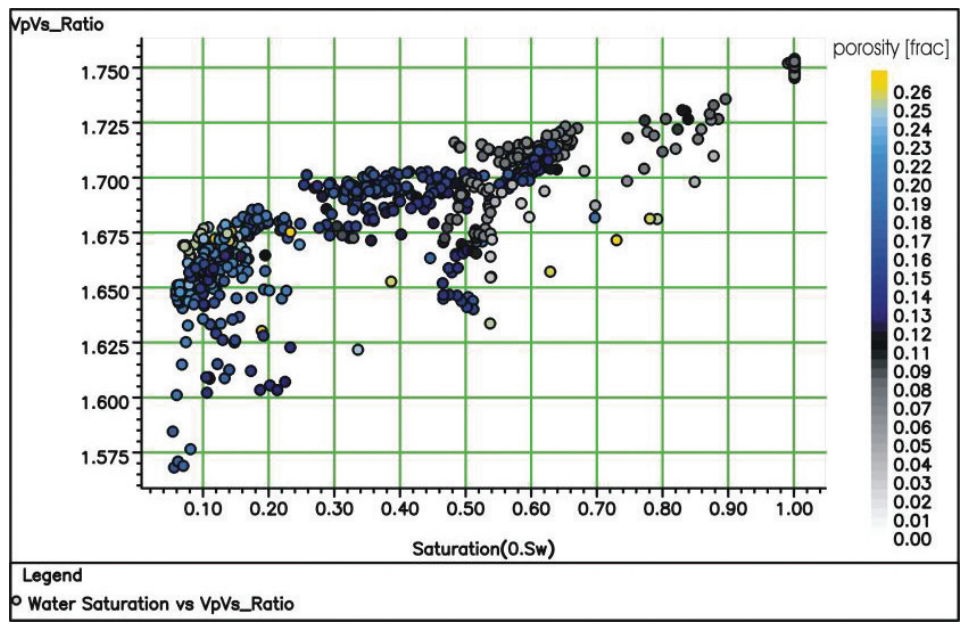

Fig. 7. Crossplot $V_{P} V_{S}$ ratio versus water saturation for $m=1.88$; colour means porosity 
For high porosity samples low water saturation was observed, and low $V_{P} / V_{S}$. In gas saturated zones a higher diversity of P-wave velocity than in S-wave velocity is observed. The higher gas saturation is associated with lower $V_{P} / V_{S}$ ratio. Fractures and microfractures play an important role. In the analysed intervals fractures and microfractures reached maximum average fracture spread equal to $0.43 \mathrm{~mm}$.

\section{DISCUSSION}

Apart from petropysical parameters (Semyrka et al. 2008) many authors analyzed variability of other the Main Dolomite parameters like geological, geophysical, geochemical and peleogeographical (Pikulski 2004, Jaworski \& Mikołajewski 2007, Kotarba \& Wagner 2007). These authors carried out their research on the Main Dolomite in the Gorzów Wielkopolski - Międzychód - Lubiatów area (Fig. 1). In the same lithofacies zone in the Main Dolomite vertical diversification of petrophysical parameters was observed (Semyrka et al. 2008). The Main Dolomite of lagoonal facies may be also divided into three zones in the Chartów W area (Fig. 1). Well logging interpretation provides us with information about vertical diversity of the Main Dolomite formation but well logging results enable to confirm seismic method results and also determine spatial porosity distribution. Seismic inversion in the Międzychód - Sieraków area (Fig. 1) for the Main Dolomite rocks was made by Solarski (2010) providing with porosity distribution. The authors used the inversion based model for the analyzed area. On the seismic section, anomalous velocity zone (velocity decrease) is recognized within the Main Dolomite formation (Fig. 4). The lowest velocity values (Fig. 4) and the highest porosity values (Fig. 5) are marked in the central part of anomaly zones.

Modelling of water saturation for different cementation factors was also analyzed and discussed. Not only Borai (1987) but also other authors (Ciechanowska \& Zalewska 2004a, 2004b) described the necessity of proper cementation factor calculation. The recent authors presented the Borai formula and Shell formula for cementation factor calculations and its influence on water saturation values in A well. The fluid substitution option was developed for interpretation in sandstone - claystone geological profiles. The authors of this paper attempted to apply this method to interpretation to carbonate formation, assuming different parameters directly dedicated for carbonates reservoir, and obtained good and promising results.

\section{CONCLUSIONS}

Several, general conclusions regarding the Main Dolomite formation analysis in the Chartów W area should be pointed out:

- in the same lithofacies zone in the Main Dolomite Formation vertical diversification of petrophysical parameters is observed;

- the Main Dolomite formation may be vertically divided into three zones of various petrophysical properties; 
- seismic inversion results confirmed the vertical zonation of the Main Dolomite;

- the most promising zone was recognized in well A within the depth range of 2745$2758 \mathrm{~m}$ and characterized in general by high porosity values and a decrease in P-wave velocity values;

- three zones were categorized from the point of reservoir parameters quality: zone II, zone I, zone III;

- the highest gas saturation occurred for the cementation factor $m=1.88$, and the lowest for $m=2.60$;

- changes in P-waves velocity are more likely to be observed than case of S-waves;

- decreasing of the $V_{P} / V_{S}$ ratio may be considered as a gas indicator in the reservoir rocks;

- for high porosity samples, low water saturation and low $V_{P} / V_{S}$ ratio was observed;

- the higher gas saturation is, the lower $V_{P} / V_{S}$ ratio occurs.

The authors warmly thank the Polish Oil and Gas Company (POGC, Warsaw, Poland) for providing all necessary data. The authors are also very grateful to Profs K. Pietsch and J. Jarzyna, our Ph.D. project advisors, for care and advice.

\section{REFERENCES}

Bała M., 2009. Określenie prędkości fal poprzecznych (Vs) na podstawie danych geofizyki otworowej. Przeglad Geologiczny, 57, 12, 1057-1066.

Bała M., 2008. Modelowanie wpływu zmiennego nasycenia gazem przestrzeni parowej skat na wyniki pomiarów akustycznych i innych profilowań w otworach oraz sejsmicznych pól falowych. Projekt badawczy nr 4 T12B05629, Arbor, Kraków.

Borai A.M., 1987. A New Correlation for The Cementation Factor in Low-Porosity Carbonates. SPE Formation Evaluation, December, paper SPE 14401, 495-499.

Ciechanowska M. \& Zalewska J., 2004a. Wskaźnik struktury porowej skał $m^{*}$. Prace Instytutu Nafty i Gazu nr 130, Geopetrol 2004, Kraków, 335-339.

Ciechanowska M. \& Zalewska J., 2004b. Porównanie wskaźników struktury porowej określonych z modelu Archiego i Waxmana-Smitsa dla rdzeni wiertniczych z otworów Chałupki Dębniańskie-3 i Jesionka-4. Prace Instytutu Nafty i Gazu nr 130, Geopetrol 2004, Kraków, 819-823.

Jarzyna J., Bała M., Cichy A., Gadek W., Gasior I., Karczewski J., Marzencki K., Stadtmüller M., Twaróg W. \& Zorski T., 2002. GeoWin ${ }^{\circledR}$ - System for processing and interpretation of well logging. Proceedings of the 8th Conference and Exhibition of EEGS-European Section, Aveiro, Portugal, September 8-12 [CD only].

Jaworowski K. \& Mikołajewski Z., 2007. Oil- and gas-bearing sediments of the Main Dolomite $(\mathrm{Ca} 2)$ in the Międzychód region: a depositional model and the problem of the boundary between the second and third depositional sequences in the Polish Zechstein Basin. Przeglad Geologiczny, 55, 12/1, 1017-1024. 
Kotarba M. \& Wagner R., 2007. Generation potential of the Zechstein Main Dolomite (Ca2) carbonates in the Gorzów Wielkopolski-Międzychód-Lubiatów area: geological and geochemical approach to microbial-algal source rock. Przeglad Geologiczny, 55, 12/1, 1025-1036.

Krakowska P. \& Niepsuj M., 2010. Influence of cementation factor on water saturation in carbonates of Main Dolomite in north-west Poland. 72nd EAGE Conference and Exhibition incorporating SPE EUROPEC 2010 in Barcelona, Extendes Abstracts, Publications Base Earth Doc EAGE, on-line: www.eage.org.

Krakowska P., 2009. Dobór parametrów petrofizycznych węglanowych skat zbiornikowych w celu podwyższenia dokładności wyznaczenia wspótczynika nasycenia wodq. Biblioteka Wydziału Geologii, Geofizyki i Ochrony Środowiska AGH, Kraków [Ms.C. Thesis]. Landmark, 2009. Landmark Graphics Corporation International Strategic University Grant Agreement, No. 2009-UGP-008037, GeoGraphix Help.

Niepsuj M., 2009. Sejsmika 3D kluczem do precyzyjnego odwzorowania budowy strukturalno-tektonicznej platform Chartowa oraz do określenia właściwości potencjalnych skat zbiornikowych. Biblioteka Wydziału Geologii, Geofizyki i Ochrony Środowiska AGH, Kraków [Ms.C. Thesis].

Niepsuj M. \& Krakowska P., 2011. Analysis of the Main Dolomite Ca2 zonation in the NW part of Polish Lowlands using integrated seismic methods and well logging data. 73rd EAGE Conference and Exhibition incorporating SPE EUROPEC 2011 in Vienna, Conference materials, Publications Base Earth Doc EAGE, on-line: www.eage.org.

Pikulski L., 2004. Analiza paleogeograficzna utworów dolomitu głównego (Ca2) w rejonie Lubiatów-Międzychód-Grotów w aspekcie poszukiwania złóż. Nafta-Gaz, 60, 9, 397-405.

Solarski T., 2010. Porównanie porowatości utworów dolomitu głównego wyznaczonych przy pomocy różnych metod inwersji sejsmicznej. Prace Instytutu Nafty i Gazu nr 170, Geopetrol 2010, Kraków, 503-507.

Veritas DGC Inc., 2004. Hampson Russell Guide.

Wagner R., Dyjaczyński B., Papiernik B., Peryt T.M. \& Protas A., 2000. Mapa paleogeograficzna dolomitu głównego (Ca2) w Polsce. In: Kotarba M.J. (red.), Bilans i potencjał węglowodorowy dolomitu głównego basenu permskiego Polski, Archiwum WGGiOŚ AGH, Kraków. 
